\title{
Design and development of experimental models for textile structures integrated in wound dressings applied in curative therapy of inflammatory skin diseases, using specific instruments of descriptive statistics
}

\author{
DOI: $10.35530 / I T .072 .05 .1848$
}

CARMEN MIHAI

SABINA OLARU

CRISTINA GROSU

ALINA POPESCU

LAURA CHIRILA

\section{ABSTRACT - REZUMAT}

Design and development of experimental models for textile structures integrated in wound dressings applied in curative therapy of inflammatory skin diseases, using specific instruments of descriptive statistics

Wound dressing is a key factor of the wound management system, having as main objective the stimulation of the healing process for a variety of inflammatory skin diseases. To maximize the therapeutic effects, innovative medical devices with integrated drug delivery system become of real interest during the last decade. For the realization of the optimal woven fabrics used as a substrate for various active principles, such as propolis and cinnamon essential oil, the multivariate linear regression analysis was used to elaborate the conceptual models on the basis of which the experimental models of the textile supports were designed. Using as input data the characteristics of the selected yarns (breaking force, elongation at break, torsion/twist, hygroscopicity), one can predict the structural parameters of the woven fabrics (raw materials, yarn density, lengths of the underlaps) and also the assembly and adjusting parameters for the machinery from weaving preparation and weaving sectors (advance and height of the drum, reed width, drawing-in, input/output of the gripper, cross unevenness reed, stationary in maximum open lease, the moment of the grippers opening, impulse time, the moment of the shaft smoothening, etc.). The validation of the elaborated conceptual models it was confirmed by the registered yields in the range of 88-96\%, during the weaving process.

Keywords: virtual model, multivariate regression, cumulative probabilities, multiple correlation coefficient, biomaterial, structural parameters, woven fabrics

Design și realizare de modele experimentale pentru structuri textile destinate pansamentelor pentru terapia curativă a afecțiunilor inflamatorii ale pielii utilizând instrumente specifice statisticii descriptive

Pansamentul este un factor cheie al sistemului de management al rănii, având ca obiectiv principal stimularea procesului de vindecare pentru o gamă largă de afecțiuni cutanate inflamatorii. Pentru maximizarea efectelor terapeutice, în ultimul deceniu au fost dezvoltate o serie de dispozitive medicale neinvazive, prevăzute cu sisteme de eliberare controlată a medicamentului. Pentru obținerea țesăturilor optime folosite ca substrat pentru depunerea diferitelor principii active, precum propolisul și uleiul esențial de scorțișoară, a fost folosită analiza de regresie liniară multivariată cu ajutorul căreia au fost elaborate modelele conceptuale, care au stat la baza proiectării modelelor experimentale de suporturi textile. Folosindu-se ca date de intrare caracteristici ale firelor utlizate (sarcina și alungirea la rupere, torsiunea/răsucirea, higroscopicitatea), au fost predicționați parametrii structurali ai țesăturilor (materii prime, desime, lungimile segmentelor de legare), precum și parametrii de montare și reglaj ai utilajelor din preparația țesătoriei și a țesătoriei (avans și înălțime tambur, lățime în spată, năvădire, intrare/ieșire greifer, denivelare traversă de spate, staționare în rost maxim deschis, momentul deschiderii greiferelor, durata impulsului, momentul nivelării ițelor etc.). Validarea modelelor conceptuale elaborate a fost confirmată prin obținerea în timpul țeserii a unor randamente situate in intervalul 88-96\%.

Cuvinte-cheie: model virtual, regresie multivariată, probabilități cumulate, coeficient de corelație multiplă, biomaterial, parametri structurali, țesături

\section{INTRODUCTION}

Although the human skin possesses high regenerative and reparative abilities, it is constantly exposed to multiple forms of injury [1]. Dermatological pathology affects all ages: from birth (neonatal dermatology), childhood (paediatric dermatology), adulthood and older adulthood (geriatric dermatology).

Wound management is a complex process having as main objective the acceleration of the healing process, simultaneously with obtaining satisfactory results from a cosmetic point of view, respectively the healing of the tissue injury with minor scarring.

The dressing is a special class of medical textiles, being very well known as the vital role of the wound dressing in the healing processes of the skin injury, due to multiple functionalities in dermal application, not just with a protective role on the skin condition against the external environment, but also with a therapeutic role $[2,3]$. 
In comparison with the traditional dressings that have the major disadvantage of strong adhesion to the wound surface and of causing pain or even additional damage at the removal moment, this study is intended to develop innovative dressings by functionalization with emulsion or hydrogel of the appropriate textile substrates, thus obtaining high performances in terms of low adhesion to the wound surface and an optimal hydration level due to the high content of water from the emulsion or hydrogel [4].

The optimal selection of the textile substrates and of the therapeutic agents used for the functionalization represents the key factor in the manufacturing process of the dressings which, in order to be considered ideal, must meet the following requirements: it must be sterile, non-toxic and non-allergenic, must provide protection against bacterial infections, should maintain a temperature and humidity level favourable for healing; should increase the epidermal cell migration to promote the angiogenesis and the connective tissue synthesis; has to allow the exchange of gases between the injured skin area and the environment $[5,6]$. In order to obtain this, raw materials based on cotton, acetate, Lenpur and cotton blended with Rayon were selected and analysed from the physical-mechanical characteristics' point of view [7]. The obtained results were used to design four conceptual models of textile structures which serve as substrates for the functionalized wound dressings with application in curative therapy of inflammatory skin diseases.

\section{MATERIALS AND METHOD}

Using the well-known methods of regression analysis, the engineering characteristics of the textile biomaterials designed for wound dressings used in the curative therapy of various skin diseases were predicted. For this purpose, multiple experiments were carried out to determine the values of the breaking force, elongation at break, torsion/twist and hygroscopicity, for five variants of yarns obtained from various raw materials and with different linear density (table 1).

Table 1

\begin{tabular}{|c|c|c|}
\hline \multicolumn{3}{|c|}{ YARNS SUBJECTED TO EXPERIMENTS } \\
\hline \multirow{2}{*}{$\begin{array}{c}\text { Yarn } \\
\text { variant }\end{array}$} & \multicolumn{2}{|c|}{ Identification data } \\
\cline { 2 - 3 } & Raw material type & Yarn count/Fineness \\
\hline V1 & $100 \%$ acetate & $130 \mathrm{dtex} \times 1$ \\
\hline V2 & $100 \%$ cotton & $200 \mathrm{dtex} \times 2$ \\
\hline V3 & $100 \%$ Lenpur & $300 \mathrm{dtex} \times 1$ \\
\hline V4 & $100 \%$ cotton & $165 \mathrm{dtex} \times 2$ \\
\hline V5 & $\begin{array}{c}80 \% \text { cotton/ } \\
20 \% \text { Rayon+ZnO }\end{array}$ & $147 \mathrm{dtex} \times 2$ \\
\hline
\end{tabular}

The calculation of the distribution parameters was realized based on a specialized program which allows calculating the mean, the median, the mode, the standard deviation, the percentile values, the skewness and the kurtosis. The results of the statistical analysis revealed a variation coefficient less than $11 \%$ for all the evaluated characteristics, the mean of the data set being representative (therefore, the populations are homogenous) and the interquartile deviation demonstrating that there's no data variability. The whiskers are drawn from the smallest to the largest detected value, being situated within the limits of 1.5 "box" lengths; extreme cases situated at a distance larger than a length of 3 "boxes" were not recorded. More than that, the obtained values for kurtosis indices demonstrate that the maximum possible limit (1.96) has not been reached for any of the variants. In fact, there is no case of the distribution going out of the theoretical normality.

For the development of the conceptual model for textile biomaterials integrated in wound dressings for curative therapy of inflammatory skin diseases, the multiple linear regression analysis was used.

For the prediction of the main engineering characteristics, the following steps were taken:

I. Identification of dependent and independent variables (customized for each model).

$Y$ is the elongation at break of the support, $X_{1}-$ the linear density of the warp system, $X_{2}$ - the linear density of the weft system, $X_{3}-$ the torsion/twist of the warp system, $X_{4}$ - the torsion/twist of the weft system; $X_{5}$ - the hygroscopicity of the warp system; $x_{6}$ - the hygroscopicity of the weft system; $X_{7}-$ the elongation at break of the warp system, $X_{8}-$ the elongation at break of the weft system; $X_{9}$ - the tensile strength of the warp system, $X_{10}$ - the tensile strength of the weft system.

II. Determination of conceptual models of multivariate regression - multiple regression equations for 10 predictors of type:

$$
\ddot{Y}=B_{0}+B_{1}{ }^{*} X_{1}+B_{2}{ }^{*} X_{2}+\ldots+B_{n}{ }^{*} X_{n}
$$

where: $B_{0}$ is the constant of the model and $B_{1}, \ldots, B_{n}$ are the unstandardized regression coefficients calculated for each independent variable separately.

III. Construction of the cumulative probability graphs for the standard residual notes and band graphs.

The studied conceptual models are highlighted in table 2.

The graphs of the cumulative probabilities for the standard residual notes and the band graphs are represented in figures 1 and 2 for all four conceptual models developed during this research.

From the obtained data based on the statistical analysis, the results are below:

- The standard error of the predicted dependent variable (elongation at break support), for any of the four conceptual models demonstrates that the maximum standard deviation of the elongation at break is $3 \%$, if the independent variables value is known.

- The standard deviations of the unstandardized regression coefficients highlight the prediction variation interval: e.g. for the unstandardized breaking 


\begin{tabular}{|c|c|c|c|}
\hline \multicolumn{4}{|c|}{ STUDIED CONCEPTUAL MODELS } \\
\hline \multirow{2}{*}{$\begin{array}{c}\text { Conceptual } \\
\text { model }\end{array}$} & \multicolumn{2}{|c|}{ Predictors identification } & \multirow{2}{*}{ Regression equations } \\
\hline & Weft system & Warp system & \\
\hline $\begin{array}{c}\mathrm{CM} 1 \\
75 \% / 25 \% \\
\text { cotton/acetate }\end{array}$ & $\begin{array}{c}\mathrm{V} 1 \\
100 \% \text { acetate }\end{array}$ & $\begin{array}{c}\text { V2 } \\
100 \% \text { cotton }\end{array}$ & $\begin{array}{l}\text { Elongation at break }=-148.472+1.362 * \text { linear density } \mathrm{V} 1- \\
0.365{ }^{*} \text { linear density } \mathrm{V} 1-0.446 * \text { torsion } \mathrm{V} 1-0.050 * \text { twist } \mathrm{V} 2 \\
+22.155^{*} \text { hygroscopicity } \mathrm{V} 1+8.755^{*} \text { hygroscopicity } \mathrm{V} 2-9.149 \\
\text { * breaking force } \mathrm{V} 1+6.520 * \text { breaking force } \mathrm{V} 2+0.610 \text { * elon- } \\
\text { gation at break } \mathrm{V} 1-0.473{ }^{*} \text { elongation at break } \mathrm{V} 2\end{array}$ \\
\hline $\begin{array}{c}\text { CM2 } \\
62 \% / 38 \% \\
\text { cotton/Lenpur }\end{array}$ & $\begin{array}{c}\text { V3 } \\
\text { 100\% Lenpur }\end{array}$ & $\begin{array}{c}\text { V2 } \\
100 \% \text { cotton }\end{array}$ & $\begin{array}{l}\text { Elongation at break }=95.3+0.15^{*} \text { linear density } \mathrm{V} 3+4.7^{*} \text { hygro- } \\
\text { scopicity } \mathrm{V} 2+0.62{ }^{*} \text { breaking force } \mathrm{V} 2+3.7^{*} \text { elongation at break } \\
\mathrm{V} 3-0.171^{*} \text { linear density } \mathrm{V} 2-0.1^{*} \text { torsion } \mathrm{V} 3-0.1^{*} \text { twist } \mathrm{V} 2 \\
+1.45{ }^{*} \text { hygroscopicity } \mathrm{V} 3-7.32{ }^{*} \text { breaking force } \mathrm{V} 3+0.7^{*} \\
\text { elongation at break } \mathrm{V} 2\end{array}$ \\
\hline $\begin{array}{c}\text { CM3 } \\
100 \% \text { cotton }\end{array}$ & $\begin{array}{c}\text { V4 } \\
100 \% \text { cotton }\end{array}$ & $\begin{array}{c}\text { V2 } \\
100 \% \text { cotton }\end{array}$ & $\begin{array}{l}\text { Elongation at break }=122.94+0.01^{*} \text { linear density } \mathrm{V} 4+3.68 \text { * } \\
\text { hygroscopicity } \mathrm{V} 2+4.38 * \text { breaking force } \mathrm{V} 2+1.61^{*} \text { elongation } \\
\text { at break } \mathrm{V} 4+0.03 * \text { linear density } \mathrm{V} 2+0.02{ }^{*} \text { twist } \mathrm{V} 4-0.002 \text { * } \\
\text { twist } \mathrm{V} 2-11.26{ }^{*} \text { hygroscopicity } \mathrm{V} 4-12.26{ }^{*} \text { breaking force } \mathrm{V} 4 \\
-2.23^{*} \text { elongation at break } \mathrm{V} 2\end{array}$ \\
\hline $\begin{array}{c}\text { CM4 } \\
95 \% / 5 \% \\
\text { cotton/Rayon+ } \\
\text { ZnO }\end{array}$ & $\begin{array}{c}\text { V5 } \\
\text { 80\%/20\% } \\
\text { cotton/Rayon+ } \\
\text { ZnO }\end{array}$ & $\begin{array}{c}V 2 \\
100 \% \text { cotton }\end{array}$ & $\begin{array}{l}\text { Elongation at break }=245.34-0.26 \text { * linear density } \mathrm{V} 2-2.27 \text { * } \\
\text { hygroscopicity } \mathrm{V} 2+4.282^{*} \text { breaking force } \mathrm{V} 2-0.58{ }^{*} \text { elongation } \\
\text { at break } \mathrm{V} 2-0.02 * \text { twist } \mathrm{V} 2-0.22{ }^{*} \text { linear density } \mathrm{V} 5-0.007 \text { * } \\
\text { twist } \mathrm{V} 5-8.70{ }^{*} \text { hygroscopicity } \mathrm{V} 5+6.58{ }^{*} \text { breaking force V5 } \\
2.40^{*} \text { elongation at break V5 }\end{array}$ \\
\hline
\end{tabular}

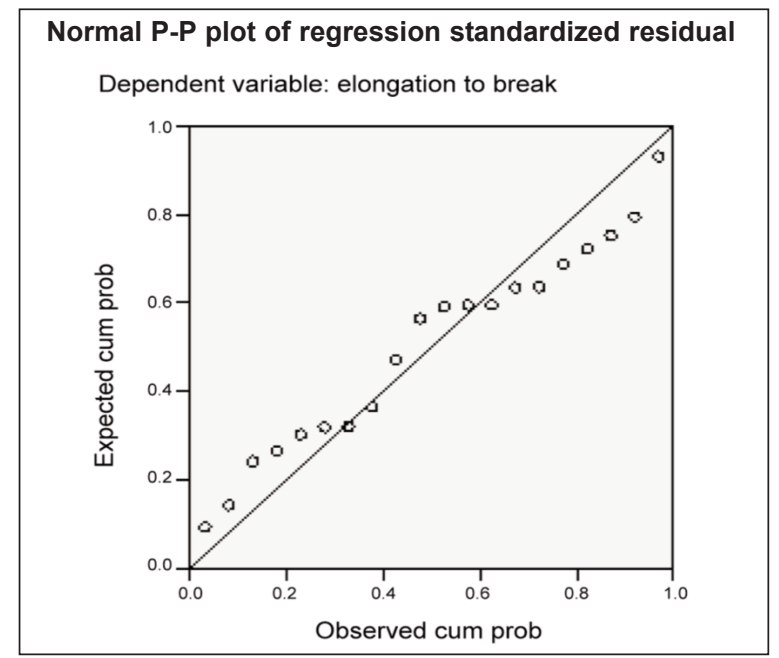

a

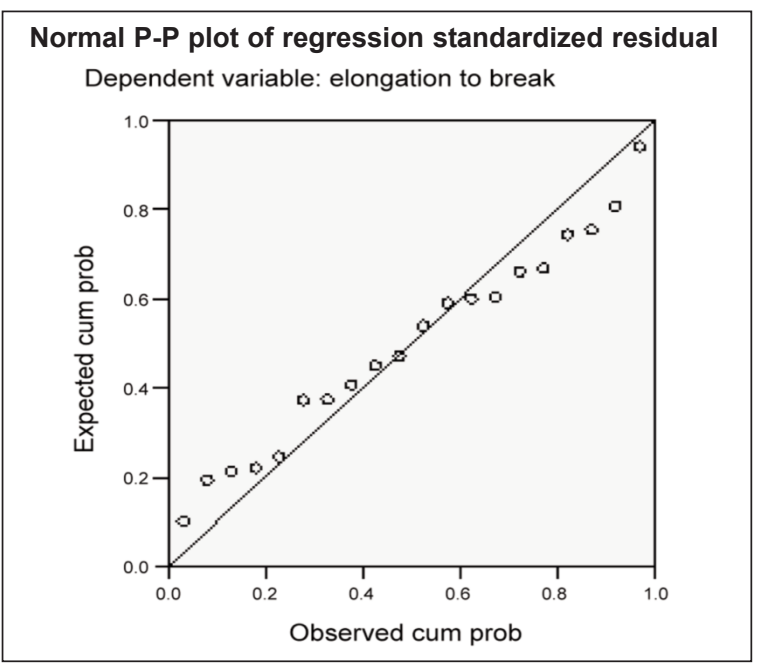

c

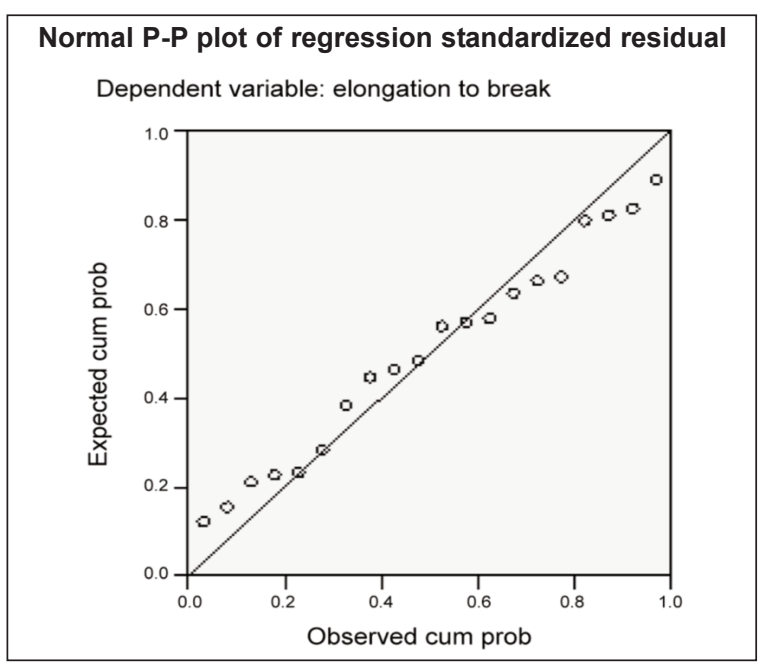

b

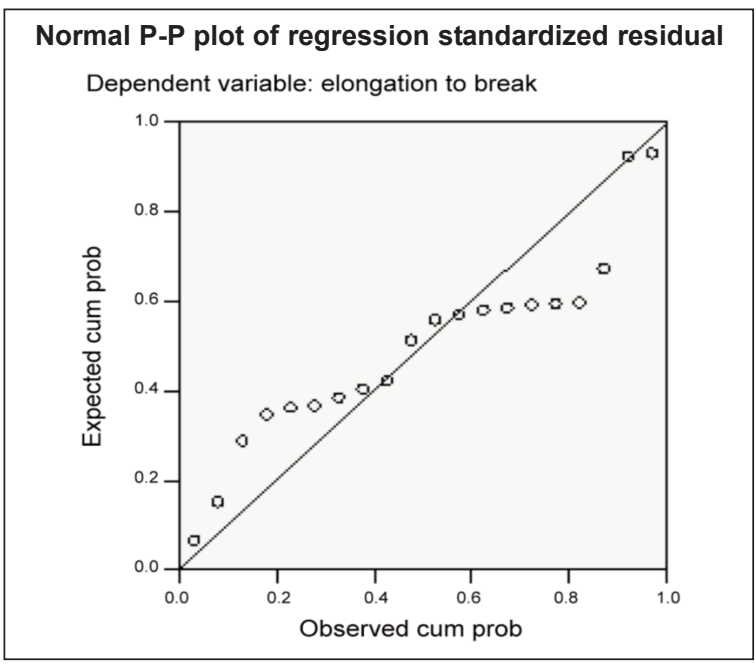

d

Fig. 1. Graphical representation of the standardized residual distribution compared to the normal distribution for: $a-\mathrm{CM} 1 ; b-\mathrm{CM} 2 ; c-\mathrm{CM} 3 ; d-\mathrm{CM} 4$ 

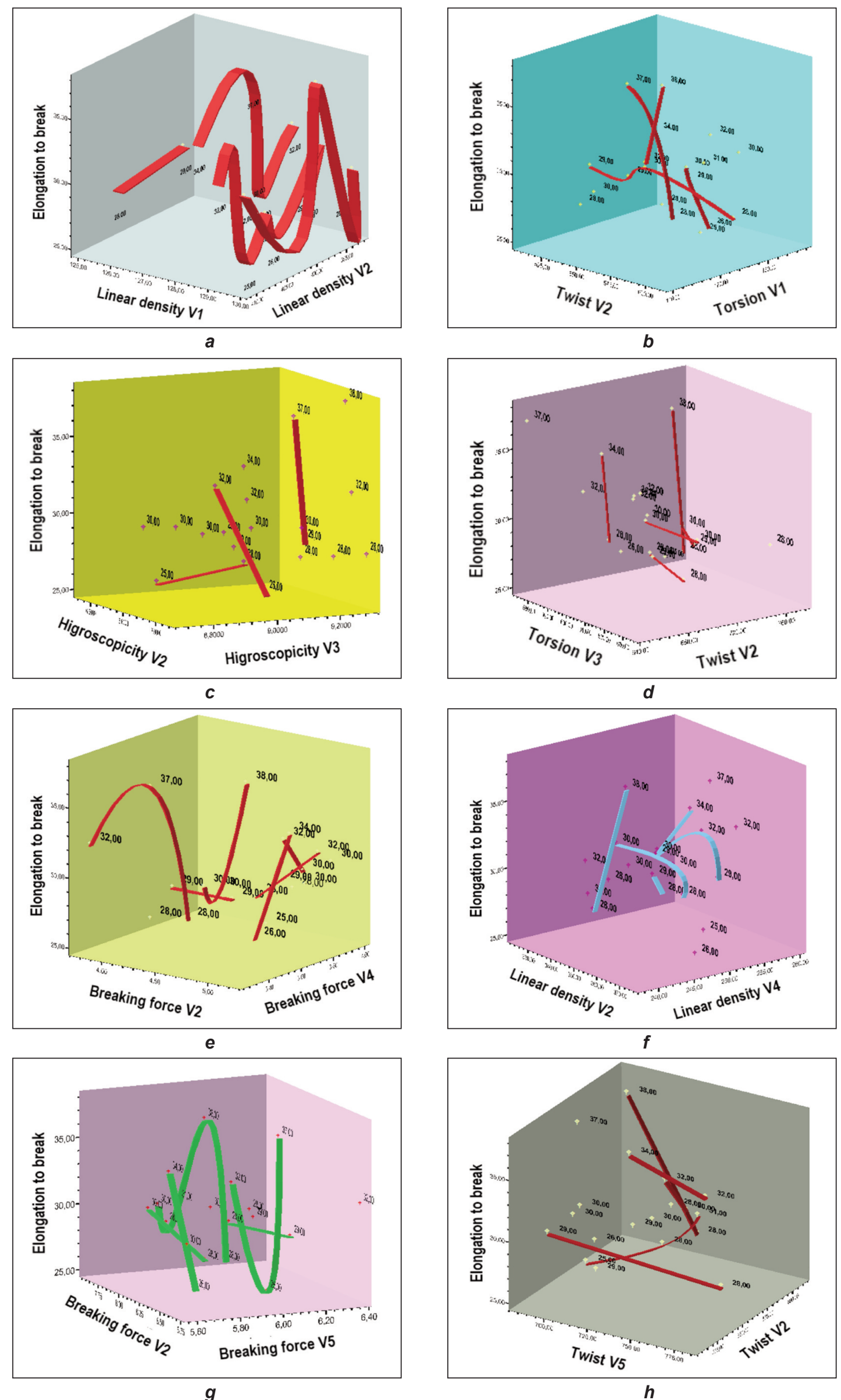

Fig. 2. Graphical representation of the elongation at break of the support depending of: $a$ - linear density of the yarns (V1 and V2) - for CM1; $b$ - torsion (V1) and twist (V2) - for CM1; $c$ - hygroscopicity (V3 and V2) - for CM2; $d$ - torsion (V3) and twist (V2) - for CM2; $e$ - breaking force (V4 and V2) - for CM3; $f$ - linear density (V4 and V2) - for CM3; $g$ - breaking force (V2 and V5) - for CM4; $h$ - twist (V2 and V5) - for CM4 
force coefficient, the standard deviation is of maximum 11.5, a fact explained by the assembly and adjusting parameters of the technological flow used during the spinning process and by the non-uniformity of the fibre in terms of length and diameter, etc.

- The variant analysis shows, with an error probability of $5 \%$, that the model explains significantly much of the variation of the dependent variable. The values of the note $\mathrm{F}$ demonstrate that the explained variation by the model is significantly higher than the residual one, and so, the developed model is efficient in prediction. The average deviation of the conceptual model from reality is about $2 \%$, more or less. Still, other specific factors of the technological flow must be taken into account to accurately predict the values of the dependent variable.

- The points corresponding to the cumulative probabilities obtained from the regression model follow those of the normal curve, so the developed conceptual model is valid. The scores predicted according to the above equations were estimated, because the correlation between the variables is not perfect, and the more error, the lower the correlation between the variables (the points of the correlation graph being farther from the regression line). So, for certain values of the dependent variable (depending on the variant of the conceptual model), it tends to overestimate or underestimate the reality.

- Band type graphics highlight the probable evolution of the elongation at break of the support (dependent variable) in accordance with predictive variables (Lagrange interpolation $3^{\text {rd }}$ order).

- These findings highlighted after analysing the resulted information from the statistical calculation served as a basis from which to start the design for the experimental models of woven textile structures used as dressings in the curative therapy of various skin diseases [8-10].

\section{RESULTS}

Specific design parameters (fibre composition and yarn count for warp and weft systems, density of yarns on weft direction and the weave pattern) relat- ed to each variant of the structure, coded EM1 EM4, are presented in table 3.

The weave pattern programming scheme is presented in figure 3.

During the entire technological process, the yarns used to obtain the textile structures EM1 - EM4 presented an appropriate behaviour; no unusual phenomena were reported and the registered yields were similar to those from the weaving preparation (at warping, drawing-in, reeding). During the weaving process, the obtained yields were situated in the range of $88-96 \%$, the stationary, mainly due to the warp yarns (a regular situation for a weaving machine for cotton and cotton type yarns), and so, for a theoretical BRO of 13800 , the lowest obtained value was 12185 , which corresponds to a yield of at least $88.3 \%$.

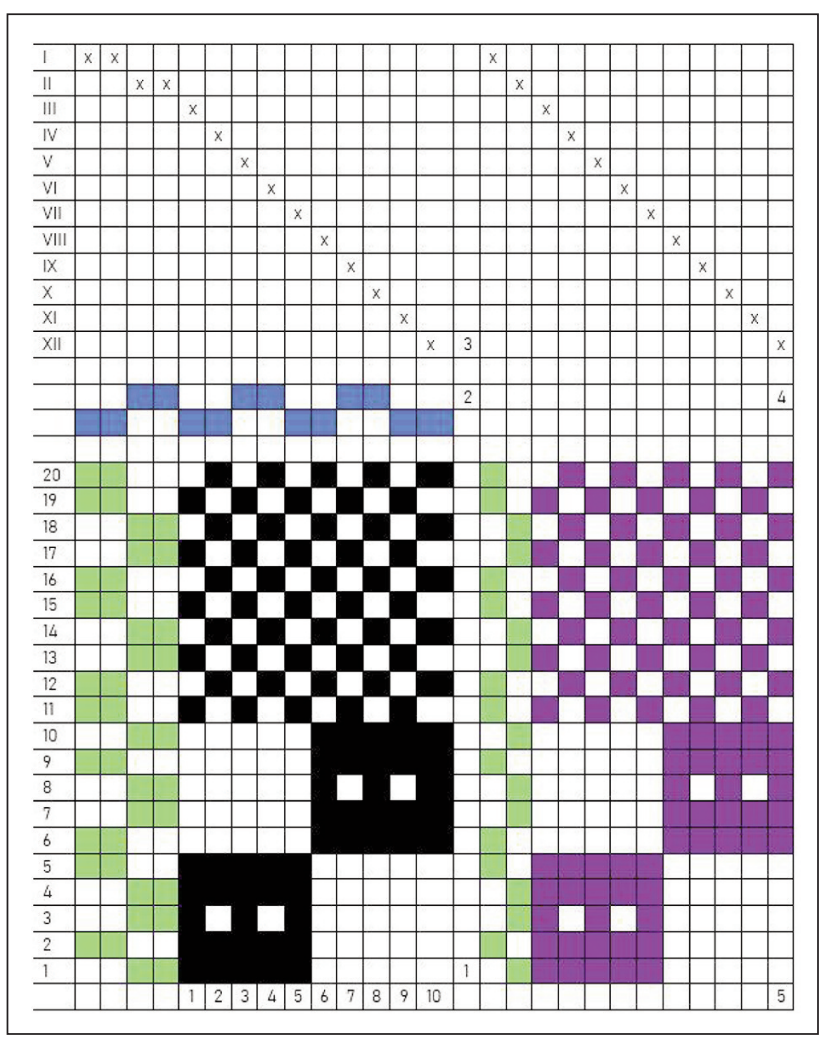

Fig. 3. The weave pattern programming scheme for experimental models of textile structures EM1 - EM4: 1 - weave pattern; 2 - reeding; 3 - drawing-in; 4 - sinkers linkage; 5 - the card

\begin{tabular}{|c|c|c|c|c|c|c|}
\hline \multicolumn{7}{|c|}{ SPECIFIC DESIGN PARAMETRES } \\
\hline \multirow{3}{*}{$\begin{array}{l}\text { Textile } \\
\text { support }\end{array}$} & \multicolumn{5}{|c|}{ Parameters } & \multirow{3}{*}{ Weave pattern } \\
\hline & \multicolumn{2}{|c|}{ Fibre composition (\%) } & \multicolumn{2}{|c|}{ Linear density (dtex) } & \multirow{2}{*}{$\begin{array}{l}\text { Weft yarn density } \\
\text { (yarns/10 cm) }\end{array}$} & \\
\hline & Weft & Warp & Weft & Warp & & \\
\hline EM1 & $100 \%$ cotton & $100 \%$ acetate & 200 dtex $\times 2$ & $130 \mathrm{dtex} \times 1$ & 365 & \\
\hline EM2 & $100 \%$ cotton & $100 \%$ Lenpur & $200 \mathrm{dtex} \times 2$ & $300 \mathrm{dtex} \times 1$ & 285 & \\
\hline EM3 & $100 \%$ cotton & $100 \%$ cotton & 200 dtex $\times 2$ & 165 dtex $\times 2$ & 260 & \\
\hline EM4 & $100 \%$ cotton & $\begin{array}{c}80 \% / 20 \% \\
\text { cotton/Rayon+ZnO }\end{array}$ & 200 dtex $\times 2$ & $147 \mathrm{dtex} \times 2$ & 270 & \\
\hline
\end{tabular}




\section{CONCLUSIONS}

The elaborated conceptual models based on the multivariate linear regression analysis allowed the designing of the experimental models for textile structures integrated in wound dressings that have been applied in curative therapy of inflammatory skin diseases.

The regression equations allowed the prediction of the structural parameters (yarn density, raw materials, lengths of the underlaps) and assembly and adjusting parameters for the machinery from weaving preparation and weaving sectors (advance and height of the drum, reed width, drawing-in, input/output of the gripper, cross unevenness reed, stationary in maximum open lease, the moment of the grippers opening, impulse time, the moment of the shaft smoothening, etc.).

\section{ACKNOWLEDGEMENTS}

This work was carried out through the Nucleu Programme, with the support of MEC, project no. 4N/08.02.2019, PN 19 1703 01, project title: "Multifunctional integrated systems based on nanocomposites and pharmacodynamic therapeutic agents for different skin conditions - BIOPANTEX".

\section{REFERENCES}

[1] Takeo, M., Lee, W., Ito, M., Wound Healing and Skin Regeneration, Cold Spring Harbor Perspectives in Medicine, 2015, http://doi.org/10.1101/cshperspect.a023267

[2] Rajendran, S., Advanced Textiles for wound Care, 2nd Edition, Woodhead Publishing, 2018

[3] Subtirica, A.I., Banciu, C.A., Chivu, A.A.-M., Dinca, L.C., Nanofibres made from biocompatible and biodegradable polymers, with potential application as medical textiles, In: Industria Textila, 2018, 69, 1, 55-58, http://doi.org/ 10.35530/IT.069.01.1502

[4] Simoes, D., Miguel, S.P., Ribeiro, M.P., Coutinho, P., Mendonca, A.G., Correia, I.J., Recent advances on antimicrobial wound dressing: A review, In: European Journal of Pharmaceutics and Biopharmaceutics, 2018, 127, 130-141, https://doi.org/10.1016/j.ejpb.2018.02.022

[5] Kellie, G., Developments in nonwovens for wound dressings, Uzun, M. Eds., Advances in technical Nonwovens, Woodhead Publishing, 2016, 443-472

[6] Ehterani, A., Salehi, M., Farzamfar, S., Vaez, A., Samadian, H., Sahrapeyma, H., Mirzaii, M., Ghorbani, S., Goodarzi, A., In vitro and in vivo study of PCL/COLL wound dressing loaded with insulin-chitosan nanoparticles on cutaneous wound healing in rats model, In: Int. j. Biol. Macromol., 2018, 1, 117, 601-609, 2018, https://doi.org/ 10.1016/j.ijbiomac.2018.05.184

[7] Chirilă, L., Constantinescu, G.C., Danila, A., Popescu, A., Constantinescu, R.R., Săndulache, I.-M., Functionalization of textile materials with bioactive polymeric systems based on propolis and cinnamon essential oil, In: Industria Textila, 2020, 71, 2, 186-192, http://doi.org/10.35530/IT.071.02.1793

[8] Lungu, O., SPSS 10.0, 2007, 44-65

[9] Levesque, R., SPSS Programming and Data Management, 4th Edition, Chicago, 2007

[10] Weinberg, S.L., Abramowitz, S.K., Data Analysis for the Behavioral Sciences Using SPSS, 2002

Authors:

CARMEN MIHAI, CRISTINA GROSU, LAURA CHIRILA, SABINA OLARU, ALINA POPESCU

National Research Development Institute for Textiles and Leather, 16 Lucretiu Patrascanu Street, 030508, Bucharest, Romania

\section{Corresponding author:}

CRISTINA GROSU

e-mail: cristina.grosu@incdtp.ro 